\title{
RESEARCH NOTE \\ Effects of sulfur fertilization on wheat production and industrial quality (Triticum aestivum)
}

\author{
Luis E. Herrera, Hernán Pinilla, and Héctor Sanhueza \\ Facultad de Ciencias Agropecuarias y Forestales, Universidad de La Frontera, Avenida Francisco Salazar \\ 01145, Temuco, Chile.
}

\begin{abstract}
L.E. Herrera, H. Pinilla, and H. Sanhueza. 2012. Effects of sulfur fertilization on wheat production and industrial quality (Triticum aestivum). Cien Inv. Agr. 39(1): 193-199. Two wheat fertilization experiments were conducted during the 2005-2006 and 2007-2008 seasons using a medial, mesic, seric, Typic Placandept soil to determine the effect of sulfur on the yield, percentage of protein, gluten content, and sedimentation volume of the grain and the nutrient availability in the soil. During the 2005-06 season, the fertilization treatments consisted of a base fertilization plus various sulfur treatments: $0 \mathrm{~kg} \mathrm{~S}^{-1}(\mathrm{~T} 1) ; 27 \mathrm{~kg} \mathrm{~S}^{-1}$ (T2); $54 \mathrm{~kg} \mathrm{~S}$ $\mathrm{ha}^{-1}$ (T3) or $108 \mathrm{~kg} \mathrm{~S} \mathrm{ha}^{-1}$ (T4). During the 2007-08 season, the fertilization treatments were

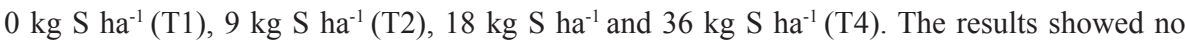
differences $(\mathrm{P}<0.05)$ in the grain yield for any of the treatments evaluated. Furthermore, no increases were found for any of the industrial quality variables analyzed. In contrast, increases in the availability of sulfur in the soil were observed. Sulfur application in soils having contents of 12 and $13 \mathrm{mg} \mathrm{kg}^{-1} \mathrm{~S}$ did not increase the grain yield, protein content, gluten, or sedimentation volume.
\end{abstract}

Key words: Triticum aestivum, wheat quality, sulfur, gluten.

\section{Introduction}

Currently, the industrial quality of wheat in Chile is extremely important in terms of the wheat value and marketing. The gluten content is one of the most influential variables in the price of the grain, which must meet minimum quality requirements for market and to be competitive. The grain quality of wheat is determined by genetic factors, the environment and the crop management, which includes nitrogen and sulfur as the

Received April 14, 2010. Accepted August 26, 2011. Corresponding author: herreral@ufro.cl fertilization used in Chile. It has been proven that sulfur is essential for the production of proteins, as it is a component of amino acids as cysteine and methionine (Duke and Reisenauer, 1986); however, it is unclear whether the application of sulfur generates changes in the amount of protein or only in the proteic composition of gluten (Zhao et al., 1999a). Wieser et al. (2004), Tea et al. (2005) and Lerner et al. (2006) described that sulfur fertilization did not influence the amount of total protein comprising gluten or the crude protein content of wheat flour, whereas it did affect the amount and proportions of individual 
types of gluten proteins, increasing high-sulfur reserve protein concentrations and reducing lowsulfur proteins.

Most of the sulfur in the mature wheat grain is present in proteins as cysteine and methionine residues (Byers et al., 1987), and cysteines play an important role in the polymerization of glutenin subunits and in the formation of the gluten network (Dupont and Altenbach, 2003). Wheat storage proteins differ in the content of cysteine residues and can be classified into proteins with high and low sulfur contents. Regarding requirements, winter wheat needs 2-3 kilograms of sulfur to produce 1 ton of grain under conditions of normal sulfur concentrations (McGrath et al., 1996). In this sense, Zhao et al. (1997) described that the total sulfur absorption by winter wheat varies between 15 and $25 \mathrm{~kg} \mathrm{ha}^{-1}$ for the production of 75 to $100 \mathrm{qqm} \mathrm{ha}^{-1}$.

Martin (1997) indicated that, when the sulfur concentration available in the soil is greater than $4 \mathrm{mg}$ $\mathrm{kg}^{-1}$, the production is not affected. Rodriguez et al. (2001) and Alfaro et al. (2006) indicated a level of $12 \mathrm{mg} \mathrm{kg}^{-1}$ as critical for wheat, and Mellado (2007) described $6 \mathrm{mg} \mathrm{kg}^{-1}$ as the critical soil level at a $0-20 \mathrm{~cm}$ soil depth. Recently, sulfur deficiencies in certain soils have been observed due to a decrease in sulfur deposition caused by industrial atmospheric acid (Flaete et al., 2005), random sulfur additions to soils using fertilizers containing $\mathrm{N}$ and $\mathrm{P}$ (Hagel, 2000a; Zhao et al., 1995) and increased soil removal as a result of higher crop yields. Regarding the level of extraction, breadmaking varieties have grain sulfur concentrations that are approximately $10 \%$ higher than those not of bread quality because good-quality varieties have higher concentrations of protein (Zhao et al., 1999c). However, the total absorption is generally similar, although bread wheat varieties contain more sulfur in their grain, as the non-bread quality varieties tend to have higher yields.

Based on the available data, we hypothesized that a response of the total gluten content to sulfur ap- plications is highly unlikely: sulfur fertilization does not cause increases in protein and gluten but does modify the protein composition. Because the Chilean milling industry bears the cost of sulfur fertilization in an effort to increase the total amount of gluten and not the proportion of proteins, proving the above hypothesis would result in a significant change in the fertilization strategies currently employed, as they would no longer be economical. Therefore, the goal of this study was to determine the effect of sulfur on the yield, protein percentage, gluten, and sedimentation volume of the grain and the availability of nutrients in the soil.

\section{Materials and methods}

Two experiments located at the coordinates $38^{\circ} 50^{\prime} 45^{\prime \prime} \mathrm{S}$ and $72^{\circ} 41^{\prime} 55^{\prime \prime} \mathrm{W}$, the IX Region, Chile, were conducted during the 2005-2006 and 2007-2008 seasons in a medial, mesic, seric, Typic Placandept soil, as described by Mella and Künhe (1985), and in the central plain agroclimatic area described by Rouanet (1983) as Mediterranean cold. For both of the seasons, the experimental design consisted of completely randomized blocks distributed in plots of $12 \mathrm{~m}^{2}(2 \times 6 \mathrm{~m})$, with four treatments including the control and four replicates. The sulfur content of the soil was 12 and $13 \mathrm{mg} /$ $\mathrm{kg}^{-1}$ for the 2005-2006 and 2007-2008 seasons, respectively. Other chemical soil characteristics are shown in Table 1.

For the 2005-2006 season, the Dollinco-INIA variety of alternative growth was used, with a white awnless spike and red grains. Sowing was performed on August 2. All of the experimental units received a base fertilization consisting of $30 \mathrm{~kg} \mathrm{~N} \mathrm{ha}^{-1}$ as sodium nitrate, $180 \mathrm{~kg} \mathrm{P}_{2} \mathrm{O}_{5}$ $\mathrm{ha}^{-1}$ as triple superphosphate, $65 \mathrm{~kg} \mathrm{~K}_{2} \mathrm{O} \mathrm{ha}^{-1}$ as potassium chloride and $1 \mathrm{~kg} \mathrm{~B} \mathrm{ha}^{-1}$ as Boronat 32 (Boronatrocalcita, granulated ulexite, Soquimich, Santiago, Chile). The treatments were as

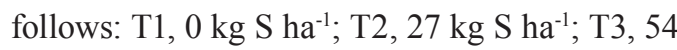
$\mathrm{kg} \mathrm{S} \mathrm{ha}^{-1}$ and T4, $108 \mathrm{~kg} \mathrm{~S} \mathrm{ha}^{-1}$. Top dressing was 
Table 1. Initial soil chemical analysis of an Andisol of Freire soil series $(0-20 \mathrm{~cm}$ depth).

\begin{tabular}{lcc}
\hline & \multicolumn{2}{c}{ Value } \\
\cline { 2 - 3 } Component & $2005-2006$ & $2007-2008$ \\
\hline $\mathrm{pH}$ & 5.93 & 5.84 \\
Organic matter (\%) & 15 & 15 \\
Olsen-P (mg kg $\left.{ }^{-1}\right)$ & 10 & 16 \\
$\mathrm{~K}\left(\mathrm{mg} \mathrm{kg}^{-1}\right)$ & 121 & 129 \\
$\mathrm{Al} \mathrm{saturation}(\%)$ & 1.85 & 0.8 \\
Sum of basic cations $\left(\mathrm{cmol}^{+} \mathrm{kg}^{-1}\right)$ & 5.84 & 8.75 \\
$\mathrm{~S}\left(\mathrm{mg} \mathrm{kg}^{-1}\right)$ & 12 & 13 \\
\hline
\end{tabular}

applied using sulfate calcium at the Z-22 stage. A maximum dose of $108 \mathrm{~kg} \mathrm{~S} h a^{-1}$ was used based on the work reported of Zhao et al. (1999b) who found an effect in the wheat quality at the dose of $100 \mathrm{~kg} \mathrm{ha}^{-1}$.

Sowing for the 2007-2008 season occurred on July 19. The basic fertilization applied at planting consisted of $28 \mathrm{~kg} \mathrm{~N} \mathrm{ha}^{-1}$ as sodium nitrate, $140 \mathrm{~kg} \mathrm{P}_{2} \mathrm{O}_{5}$ ha $^{-1}$ as triple superphosphate, $75 \mathrm{~kg}$ $\mathrm{K}_{2} \mathrm{O} \mathrm{ha}^{-1}$ as potassium chloride, and $2 \mathrm{~kg} \mathrm{~B} \mathrm{ha}^{-1}$ as Boronat 32. The treatments were as follows: T1 (control), $0 \mathrm{~kg} \mathrm{~S} \mathrm{ha}^{-1}$; T2, 9 kg S ha-1; T3, 18 $\mathrm{kg} \mathrm{S} \mathrm{ha}^{-1}$ and T4, $36 \mathrm{~kg} \mathrm{~S} \mathrm{ha}^{-1}$. The sulfur was applied in the furrow, generating a high availability in the rhizosphere when using lower doses of S. For both of the seasons, the total nitrogen was adjusted to $200 \mathrm{~kg} \mathrm{~N}^{-1}$ with 25 SuperNitro applied equally in two parts, at the Z-22 and Z-31 developmental stages. The variables evaluated were performance, the availability of sulfur in the soil and the industrial quality of the grain.

To calculate the yield, 36 linear meters from the center of each plot were harvested. The percentage of the grain moisture at harvest was determined, and the grain yield was standardized to $14 \%$ humidity. After verifying the homogeneity of variance and normal distribution of data, an analysis of variance (ANOVA) was performed us- ing SPSS (Statistical Package for Social Sciences, 2004. SPSS Base 12.0 User's Guide for Windows. SPSS Inc., Chicago, Illinois, USA). The means were compared using the Tukey test $(\mathrm{P} \leq 0.05)$.

The availability of sulfur in the soil was measured for the 2005-2006 season using two samples of the soil between rows at the Z-31 and Z-59 developmental stages (Zadoks et al., 1974). The goal was to assess the availability of this nutrient during the phenological stages that present the highest sulfur concentration. For the 2007-2008 season, the sampling was conducted within rows at harvest (in Z-94), with the goal of assessing S availability once the total absorption of the crop was completed. For each repetition, five subsamples were randomly sampled, totaling twenty sub-samples, and were homogenized to obtain a sample for each treatment. A PVC (Polyvinyl chloride) plastic tube (5 $\mathrm{cm}$ in diameter) was used to collect the sample at a depth of 0-20 cm. The samples were analyzed by the Soil and Plant Laboratory of the Institute of Agribusiness at the University of La Frontera for soil $\mathrm{pH}$, sum of bases, available sulfur extracted with $\mathrm{Ca}\left(\mathrm{H}_{2} \mathrm{PO}_{4}\right)$ $0.01 \mathrm{~mol} \mathrm{~L}^{-1}$ and aluminum saturation percentage.

The industrial quality of the grain was assessed based on a sample of grain, analyzing the total protein, wet gluten and SDS sedimentation volume. The respective analyses were performed at the wheat quality laboratory of the National Institute of Agricultural Research, Carillanca Station, according to the methods and procedures established by the Chilean Norm 1237 (INN, 2000).

The protein content of the grain was determined using the Kjeldahl method, according to the Chilean Standard No. 513 (INN, 1968), which consists of a series of processes based on the removal and destruction of organic matter, resulting in only nitrogen in the sample, which is ultimately converted into the percentage of protein.

To determine the gluten index, the wet and dry gluten, a sample of flour dough was prepared by 
adding a buffered solution of sodium chloride. The sedimentation volume was determined by the microsedimentation method, according to the protocol described by Chilean Norm 1237 (INN, 2000).

\section{Results and discussion}

\section{Grain yield}

At available sulfur levels of 12 and $13 \mathrm{mg} \mathrm{kg}^{-1}$, no significant differences in performance were observed for the different sulfur doses tested $(\mathrm{P} \leq 0.05)$, with an average of $86.7 \mathrm{qqm} \mathrm{ha}^{-1}$ for the $2005 / 06$ season and $93.92 \mathrm{qqm} \mathrm{ha}^{-1}$ for the $2007 / 08$ season. These results are similar to those reported by Martin (1997), Rodriguez et al. (2001), Alfaro et al. (2006) and Mellado (2007) for the critical levels of available sulfur extracted with $\mathrm{Ca}\left(\mathrm{H}_{2} \mathrm{PO}_{4}\right) 0.01 \mathrm{~mol} \mathrm{~L}^{-1}$. Therefore, at the comparable sulfur levels, it would be unlikely to find increased grain yield by applying this nutrient.

Because of the relationship between $\mathrm{N}$ and $\mathrm{S}$ nutrition, yield responses to $\mathrm{S}$ fertilization often depend on the amount of nitrogen fertilizer applied. Flaete et al. (2005) found that the yield response to $\mathrm{S}$ application is generally greater when high amounts of $\mathrm{N}$ are applied.

The sulfur doses evaluated in this study to increase wheat production and industrial quality are within the range of the doses used in several other wheat studies. Zhao et al. (1999b) used doses of 20 and $100 \mathrm{~kg} \mathrm{~S} \mathrm{ha}^{-1}$, Luo et al. (2000) applied a single dose of $50 \mathrm{~kg} \mathrm{~S} \mathrm{ha}^{-1}$, Hagel (2000b) evaluated soil doses of 20, 40 and $60 \mathrm{~kg}$ ha-1 S, Engle et al. (2002) used doses of $0,10,20$ and $30 \mathrm{~kg} \mathrm{~S}^{-1}$, and Flaete et al. (2005) evaluated doses of 10 and $30 \mathrm{~kg} \mathrm{~S} \mathrm{ha}^{-1}$.

\section{Availability of sulfur in the soil}

For both of the seasons, our results indicate that the sulfur additions generated increases in the nutrient availability in the soil at the different stages of development evaluated (Figure 1).

It was observed that the increase of the sulfur dose applied at Z-22 was positively correlated to
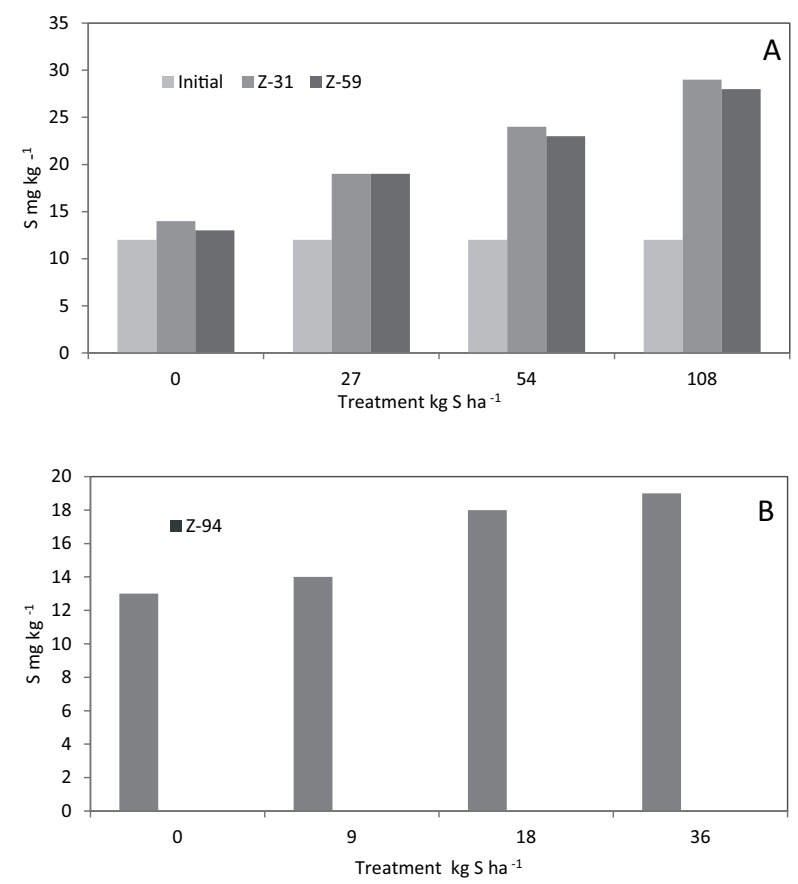

Figure 1. Availability of sulfur in the soil at different growth stages, A: 2005-2006, at Z-00 (initial), Z-31 and Z-59; B: 2007-2008, at Z-94. 
an increase of this nutrient in the soil, indicating that calcium sulfate is a good alternative to increase the availability of sulfur in the soil. A slight decrease in the availability of $\mathrm{S}$ between the Z-31 and Z-59 stages was also observed, probably due to the higher level of extraction of the plants as development progressed. In this regard, the reproductive period of wheat is the most sensitive to $\mathrm{S}$ deficiency, evidencing a decrease in the grain size under limiting conditions (Zhao et al., 1999a). After the furrow sulfur applications in the second season, there was a significant increase in the sulfur availability measured at harvest, indicating that this is a viable alternative fertilization in the management of wheat. Comparing the two forms of S application normally used for this crop, the average increase in the availability of $\mathrm{S}$ was $1 \mathrm{mg}$ $\mathrm{kg}^{-1}$ for every $6.5 \mathrm{~kg}$ of $\mathrm{S}$ applied by top dressing and $6 \mathrm{~kg}$ of $\mathrm{S}$ for the furrow application.

\section{Industrial quality of the grain}

Table 2 presents the results in terms of the industrial quality of the grain based on the evaluated variables and their classification according to the Chilean Norm 1237 (INN, 2000). There were no differences in any of the quality parameters studied, concluding that the applications of sulfur did not affect the total content of gluten, the amount of protein in the grain, or the sedimentation volume.
These results are based on the fact that $\mathrm{S}$ affects the proportion of individual types of proteins present in the grain and not the quantity, which is measured by the percentage of protein and wet gluten (Zhao et al., 1997b). Our findings are in agreement with the results described by several authors that S nutrition has an effect on the composition of the grain storage proteins but not on their total content (Zhao et al., 1997b, Zhao et al., 1999c; Wieser et al., 2004; Tea et al., 2005).

From these results, the following can be concluded: (1) Sulfur applications did not produce significant changes in the grain yield of wheat in soils with initial sulfur levels of 12 and 13 mg kg-1 and did not cause increases in the total content of protein and gluten or the sedimentation volume. (2) All of the doses and forms of sulfur tested generated increases in the nutrient availability in the soil with respect to the control. (3) In the Andisol soil used, it was possible to increase the sulfur availability at a $0-20 \mathrm{~cm}$ depth to $1 \mathrm{mg} \mathrm{kg}^{-1}$ for every 6 to $6.5 \mathrm{~kg} \mathrm{~S} \mathrm{ha}^{-1}$ applied (as calcium sulfate) to the furrow and as top dressing, respectively. (4) Considering that the value of wheat in the Chilean market is influenced mainly by the total content of gluten and not by the proportion of proteins in the gluten, the use of sulfur fertilization to alter the ratio of proteins that form gluten does not have an economic benefit for the producer.

Table 2. Effect of treatments on industrial wheat quality parameters and classification according to NCH 1237.

\begin{tabular}{|c|c|c|c|}
\hline \multirow[b]{2}{*}{ Treatment } & \multicolumn{3}{|c|}{ Parameter } \\
\hline & Wet gluten $(\%)$ & Protein $(\%)$ & Sedimentation $(\mathrm{ml})$ \\
\hline \multicolumn{4}{|l|}{ Season $2005-2006$} \\
\hline Basic Fertilization & 32.4 strong & 12.8 strong & 43.5 extra \\
\hline Basic. Fert. $+27 \mathrm{~kg} \mathrm{~S} \mathrm{ha}^{-1}$ & 32.3 strong & 12.7 strong & 45.2 extra \\
\hline Basic. Fert. +54 kg S ha-1 & 32.7 strong & 12.8 strong & 43.8 extra \\
\hline Basic. Fert. +108 kg S ha ${ }^{-1}$ & 32.5 strong & 12.8 strong & 44.5 extra \\
\hline \multicolumn{4}{|l|}{ Season $2007-2008$} \\
\hline Basic Fertilization & 24.8 soft & 9.6 intermediate & 27.2 regular \\
\hline Basic Fert. $+7 \mathrm{~kg} \mathrm{~S} \mathrm{ha}^{-1}$ & $22.2 \mathrm{soft}$ & 9.3 intermediate & $24.8 \mathrm{soft}$ \\
\hline Basic Fert. $+17.5 \mathrm{~kg} \mathrm{~S} \mathrm{ha}^{-1}$ & $24.3 \mathrm{soft}$ & 9.5 intermediate & 26.4 regular \\
\hline Basic Fert. + $37.5 \mathrm{~kg} \mathrm{~S} \mathrm{ha-1}$ & $24.5 \mathrm{soft}$ & 9.6 intermediate & 26.4 regular \\
\hline
\end{tabular}




\section{Resumen}

Luis E. Herrera, H. Pinilla y H. Sanhueza. 2012. Efecto de la fertilización azufrada en la producción y calidad industrial del trigo (Triticum aestivum). Cien. Inv. Agr. 39(1): 193-199. Se realizaron dos experimentos de fertilización en trigo durante las temporadas 20052006 y 2007-2008, en un suelo Medial, mesic, Seric Placandepts, para determinar el efecto del azufre en el rendimiento del grano, porcentaje de proteína, contenido de gluten, volumen de sedimentación y la disponibilidad del nutriente en el suelo. En la temporada 2005/2006 los tratamientos consistieron en una fertilización base más azufre, $0 \mathrm{~kg} \mathrm{~S} h a^{-1}(\mathrm{~T} 1)$; $27 \mathrm{~kg} \mathrm{~S} \mathrm{ha}^{-1}$

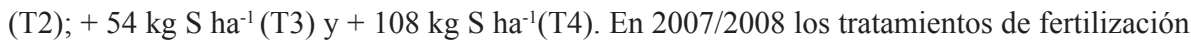
fueron base $0 \mathrm{~kg} \mathrm{~S}^{-1}$ (T1), $9 \mathrm{~kg} \mathrm{~S}^{-1}$ (T2); $18 \mathrm{~kg} \mathrm{~S}$ ha-1 y $36 \mathrm{~kg} \mathrm{~S}^{-1}$ (T4). Los resultados no mostraron diferencias $(\mathrm{P}<0.05)$ en el rendimiento de grano para los todos los tratamientos evaluados. No se registraron incrementos en ninguna de las variables de calidad industrial medidas. Se observaron aumentos en la disponibilidad de azufre en el suelo. Las aplicaciones de azufre en suelos con 12 y $13 \mathrm{mg} \mathrm{kg}^{-1}$ no generaron incrementos en rendimiento, contenido de proteína, gluten, y volumen de sedimentación.

Palabras clave: Triticum aestivum, calidad del trigo, azufre, gluten.

\section{References}

Alfaro, M., R. Bernier, and S. Iraira. 2006. Efecto de fuentes de azufre sobre rendimiento y calidad de trigo y pradera en dos andisoles. Agricultura Técnica (Chile) 66: 283-294.

Byers, M., J. Franklin, and S.J. Smith. 1987. The nitrogen and sulphur nutrition of wheat and its effect on the composition and baking quality of the grain. Aspects of Applied Biology, Cereal Quality 15 : 337-344.

Duke, S.H., and H.M. Reisenauer. 1986. Roles and requirements of sulfur in plant nutrition. In: Sulfur in Agriculture, American Society of Agronomy, Crop Science Society of America, Soil Science Society of America, Madison. Wisconsin, USA. p. 123-168.

Dupont, F.M., and S.B. Altenbach. 2003. Molecular and biochemical impacts of environmental factors on wheat grain development and protein synthesis. Journal of Cereal Science 38:133-146.

Engle, R., G. Jackson, and J. Miller, 2002. Effect of sulfur (S) and $\mathrm{S}$ application time on yield and quality of spring wheat. Northwestern Agricultural Research Center (NWARC), Creston, Montana.10 pp.

Flaete, N. E. S., K. Hollung, L. Ruud, T. Sogn, E. M. Færgestad, H. J. Skarpeid, E. M. Magnus, A. K.
Uhlen, 2005. Combined nitrogen and sulphur fertilization and its effect on wheat quality and protein composition measured by SE-FPLC and proteomics. Journal of Cereal Science 41:357-369.

Hagel, I. 2000a. Biobrot aus Schwefelmangelweizen? Ein Beitrag zur Qualitätsbeurteilung der festen Proteinstruktur moderner Weizensorten. Institut für Biologisch-Dynamische Forschung, Darmstadt, Schriftenreihe Band 14,ISBN 3-928949-14-4.

Hagel, I. 2000b. Auswirkungen einer Schwefeldüngung auf Ertrag und Qualität von Weizen. Weizenzüchtung auf hohe technologische Qualität durch induzierten Schwefelmangel. Deutsche Gesellschaft für Qualitätsforschung e.V., XXXVII. Vortragstagung, 4.-5 März. Hannover. p. 307-312.

INN. 1968. NCH 513. Materias orgánicas, Determinación de nitrógeno, Método de Kjeldahl. INN (Instituto Nacional de Normalización). Santiago, Chile. Primera edición. 3 pp.

INN. 2000. NCH 1237 - 2000. Requisitos de un trigo harinero. INN (Instituto Nacional de Normalización). Santiago, Chile. Primera edición. 16 pp.

Lerner, S.E., M.L.Seghezzo, E.R. Molfese, N.R. Ponzio, M. Cogliatti, and W. J. Rogers. 2006. Nand S-fertilizer on grain composition, industrial quality and end-use in durum wheat. Journal of Cereal Science 44: 2-11. 
Luo, C., G. Branlard, B. Griffin, and D.L. Mc Neil. 2000. The effect of nitrogen and sulphur fertilization and their interaction with genotype on wheat glutenins and quality parameters. J Cereal Sci. 31: 185-194.

Martin, R.J. 1997. Uptake and distribution of nitrogen and sulphur in two Otane wheat crops. Proceedings Agronomy Society of New Zealand 27: 19-26.

McGrath, S.P., F.J. Zhao, and P.J. Withers. 1996. Development of sulphur deficiency in crops and its treatment. Proceedings of the Fertilizer Society 379: 257-268. (The Fertilizer Society: Peterborough).

Mella, A., and G. Kühne, 1985. Sistema de descripción de las familias, asociaciones y series de suelos derivados de materiales piroclásticos de la zona central-sur de Chile. In: J. Tosso (ed.). Suelos volcánicos de Chile. Instituto de Investigaciones Agropecuarias (INIA). Ministerio de Agricultura. Santiago, Chile. Cap.1. p. 25-95.

Mellado, M. 2007. El Trigo en Chile. Cultura, ciencia y tecnología. Instituto de Investigaciones Agropecuarias (INIA). Ministerio de Agricultura. Chillán, Chile. Colección Libros INIA $\mathrm{N}^{\circ} 21.684 \mathrm{pp}$.

Rodríguez, J., D. Pinochet, and F. Matus. 2001. Fertilización de los cultivos. LOM Ediciones. Santiago, Chile. 117 pp.

Rouanet, J. 1983. Clasificación agroclimática de la IX región. Segunda aproximación. Investigación y Progreso Agropecuario Carillanca 2(4):25-27.

Tea, I., T. Genter, F. Violleau, and D. Kleiber. 2005. Changes in the glutathione thiol-disulfide status in wheat grain by foliar sulphur fertilization: consequences for the rheological properties of dough. Journal of Cereal Science 41: 305-315.

Wieser, H., R. Gutser, and S. von Tucher. 2004. Influence of sulphur fertilization on quantities and proportions of gluten protein types in wheat flour. Journal of Cereal Science 40: 239-244.

Zadoks, J., T. Chang, and C. Konzak. 1974. Código decimal para los estados de crecimiento de cereales. Weed Research 14: 415-421.

Zhao, F.J., M.J. Hawkesford, and S.P. McGrath. 1999a. Sulphur assimilation and effects on yield and quality of wheat. Journal of Cereal Science 30: 1-17.

Zhao, F.J., S.E. Salmon, P.J.A. Withers, J.M. Monaghan, E.J. Evans, P.R. Shewry, and S.P. McGrath. 1999b. Variation in the breadmaking quality and rheological properties of wheat in relation to sulphur nutrition under field conditions. Journal of Cereal Science 30: 19-31.

Zhao, F.J., S.E. Salmon, P.J.A. Withers, E. J. Evans, and S.P. McGrath. 1999c. Responses of breadmaking quality to sulphur in three wheat varieties. Journal of the Science of Food and Agriculture 79: 1865-1874.

Zhao, F.J. S.P. McGrath, S.E. Salmon, P.R. Shewry, R. Quayle, P.J.A. Withers, E.J. Evans, and J. Monahan. 1997. Optimising sulphur inputs for bread making quality of bread. Aspects of Applied Biology 50: 199-205.

Zhao, F.J., S.P. McGrath, A.R. Crosland, and S.E. Salmon, 1995. Changes in the sulfur status of British wheat-grain in the last decade, and its geographical-distribution. Journal of the Science of Food and Agriculture 68: 507-514. 
